\title{
NOTONYX GUINOTAE, A NEW SPECIES OF GONEPLACID CRAB (BRACHYURA, GONEPLACIDAE) FROM LOMBOK ISLAND, INDONESIA
}

\author{
BY \\ DWI LISTYO RAHAYU ${ }^{1,3}$ ) and PETER K. L. NG ${ }^{2,4}$ ) \\ 1) Marine Bio-Industry Implementation Unit — Research Center for Oceanography, \\ Indonesian Institute of Sciences (LIPI), P.O. Box 1124, Mataram 83000, NTB, Indonesia \\ 2 ) Tropical Marine Science Institute and Department of Biological Sciences, National \\ University of Singapore, Lower Kent Ridge Road, Singapore 119260, Republic of Singapore
}

\begin{abstract}
A new species of goneplacid crab of the genus Notonyx A. Milne-Edwards, 1873, is described from Lombok, Indonesia. The new species, $N$. guinotae, resembles $N$. kumi Naruse \& Maenosono, 2009, but differs in having a relatively more slender male abdomen, proportionately longer ambulatory legs, as well as male first and second gonopods that are different in morphology. The discovery of this new species brings the number of species now known to six.

\section{RÉSUMÉ}

Une nouvelle espèce de crabe Goneplacidae du genre Notonyx A. Milne-Edwards, 1873, est décrite de Lombok en Indonésie. Cette nouvelle espèce, $N$. guinotae ressemble à $N$. kumi Naruse \& Maenosono, 2009, mais en diffère par un abdomen male relativement plus étroit, des pattes ambulatoires relativement plus longues et également par les structures des premier et second gonopodes mâles qui sont de forme différentes. La découverte de cette nouvelle espèce porte à six le nombre d'espèces connues de ce genre.
\end{abstract}

\section{INTRODUCTION}

Members of the genus Notonyx A. Milne-Edwards, 1873 (type species Notonyx nitidus A. Milne-Edwards, 1873), are defined principally by their

\footnotetext{
3 ) Corresponding author; e-mail: dwilistyo@yahoo.com

$\left.{ }^{4}\right)$ e-mail: dbsngk1@nus.edu.sg 
quadrangular shaped and smooth carapace, without clear indication of regions, the absence of teeth or spines on the anterolateral margins, a relatively stout male first gonopod, as well as a male second gonopod which is long, whip-like, and longer than the male first gonopod. As has been discussed at length by Clark \& Ng (2006), Castro (2007), and Ng \& Clark (2008), Notonyx is clearly a member of the Goneplacidae MacLeay, 1838, despite its unusual carapace form.

This genus has been well studied in the last few years, with the identity of Notonyx nitidus A. Milne-Edwards, 1873, clarified and several new species described (Clark \& Ng, 2006; Ng \& Clark, 2008; Naruse \& Maenosono, 2009). Currently, five species are included in the genus: Notonyx nitidus A. MilneEdwards, 1873, N. vitreus Alcock, 1900, N. gigacarcinicus Clark \& Ng, 2006, N. latus Ng \& Clark, 2008, and N. kumi Naruse \& Maenosono, 2009 (see also $\mathrm{Ng}$ et al., 2008). During ecological studies of the seagrass beds of Lombok Island, Indonesia, a good number of Notonyx specimens were collected. While they superficially resemble $N$. kumi in having a swollen subdistal part of the male first gonopod, they nevertheless differ in many other morphological characters. This species is considered as new and it is described herein as N. guinotae.

The material examined is deposited in the Museum Zoologi Bogor, Indonesian Institute of Sciences, Cibinong, Indonesia; the former Rijksmuseum van Natuurlijke Historie (RMNH), Leiden, The Netherlands [now National Museum of Natural History - Naturalis]; and the Zoological Reference Collection (ZRC) of the Raffles Museum of Biodiversity Research, National University of Singapore, Rep. of Singapore. Size is indicated by the carapace width and length (carapace width $\times$ carapace length) in $\mathrm{mm}$. The terminology used in the description generally follows that of Clark \& $\mathrm{Ng}$ (2006). The abbreviations G1 and G2 refer to the male first gonopod and male second gonopod, respectively.

\section{TAXONOMY}

Family GonePlacidae MacLeay, 1838

Notonyx A. Milne-Edwards, 1873

Remarks. - The systematics of this genus was explained at length by Clark \& Ng (2006), Ng \& Clark (2008), and Castro (2007: 754). The characters of the present new species conform with all the generic and familial features recorded by these authors. 
Notonyx guinotae n. sp. (figs. 1-5)

Material. - Holotype, 1 male $(15.5 \times 11.5 \mathrm{~mm})$ (MZB Cru 2583), Sira, northern Lombok Island, $08^{\circ} 21.641^{\prime} \mathrm{S} 116^{\circ} 06.272^{\prime} \mathrm{E}$, coll. D. L. Rahayu, 13 May 2007. Paratypes: 1 female $(6.5 \times 4.7 \mathrm{~mm})($ MZB Cru 2584), 1 female $(7.5 \times 5.6 \mathrm{~mm})($ ZRC 2009.0746), same locality as holotype; 2 males $(5.9 \times 4.9 \mathrm{~mm}, 11.4 \times 8.2 \mathrm{~mm})($ ZRC 2009.0745), Kuta, central Lombok Island, coll. D. L. Rahayu, 18 August 2006; 1 male $(7.8 \times 6.0 \mathrm{~mm})($ MZB Cru 2585), Medana, northern Lombok Island, $08^{\circ} 21.791^{\prime} \mathrm{S} 116^{\circ} 07.608^{\prime} \mathrm{E}$, coll. D. L. Rahayu, 12 June $2007 ; 1$ male $(7.0 \times 5.8 \mathrm{~mm})($ MZB Cru 2586), Sekotong, western Lombok Island, coll. D. L. Rahayu, 16 May 2007.

Comparative material. - Notonyx kumi Naruse \& Maenosono, 2009, paratype male $(9.3 \times$ $6.8 \mathrm{~mm}$ ) (ZRC 2008.0022), Oh-jima Island, near Kume-jima Island, Ryukyu Islands, Japan, coll. T. Maenosono, 1 April 2008; 1 male $(6.0 \times 4.6 \mathrm{~mm})(\mathrm{RMNH})$, station 47, Bay of Bima, north coast of Sumbawa, Lesser Sunda Islands, Indonesia, 13-31 m deep, coll. SIBOGA Expedition.

Etymology. - The new species is named in honour of Danièle Guinot, a respected colleague and cherished friend, for her many contributions to carcinology, especially towards a better understanding of the Goneplacidae. The name is a noun in the genitive singular.

Diagnosis. - Holotype: carapace subquadrilateral, about 1.4 times as wide as long (fig. 1A); frontal margin gently convex, about 0.3 times width of carapace (fig. 1B). Anterolateral margin short, entire, curved, without teeth; posterolateral margin gently concave, slightly diverging posteriorly (fig. 3A); dorsal surface of carapace convex anteriorly, posteriorly; smooth, without indication of regions except for shallow impression in gastro-cardiac area. Antennules long, terminal part overreaching cornea; basal antennal segment small, short, positioned on edge of orbital hiatus. Eye peduncle moderately long, 0.6 times frontal width; cornea small, pigmented. Gape present between third maxillipeds when closed; merus and ischium subequal, quadrate; anteroexternal angle of merus forming right angle (fig. 3B). Chelipeds subequal, right one larger (fig. 2B, C); fingers relatively stout, dactylus with longitudinal shallow groove; fixed finger with slight longitudinal keel on ventral margin extending almost to tip of finger; palm smooth; inner distal edge of carpus with low spine, inner margin finely denticulate, with clump of setae (fig. 3E); merus with long, stiff setae on anterior, posterior margins. Ambulatory legs relatively long, smooth; dactylus longer than propodus, with carina on lateral surface; all segments with long, relatively dense setae on dorsal and ventral margins (fig. 3C). Thoracic sternum relatively broad; surface lightly pitted; sternites 1 , 2 fused, separated from sternite 3 by distinct transverse suture; sternites 3,4 fused with lateral incision marking somites (fig. 1C). Male abdomen triangular (figs. 1C, 2A, 3D), relatively narrow with 7 movable somites including telson; 


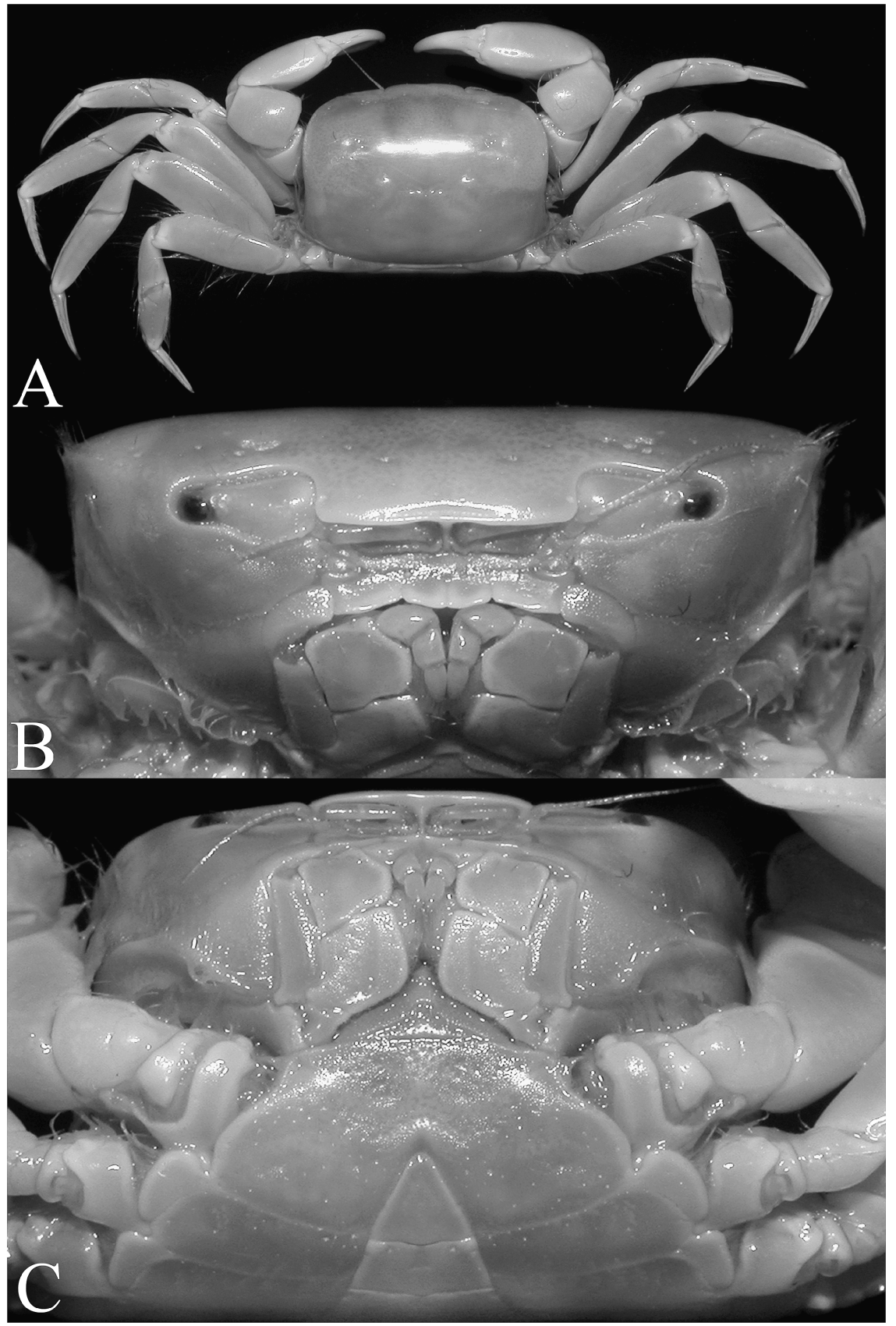

Fig. 1. Notonyx guinotae n. sp., holotype, male $(15.5 \times 11.5 \mathrm{~mm})($ MZB Cru 2583). A, overall dorsal view; $\mathrm{B}$, frontal view of carapace; $\mathrm{C}$, ventral view showing anterior part of thoracic sternum and abdomen. 


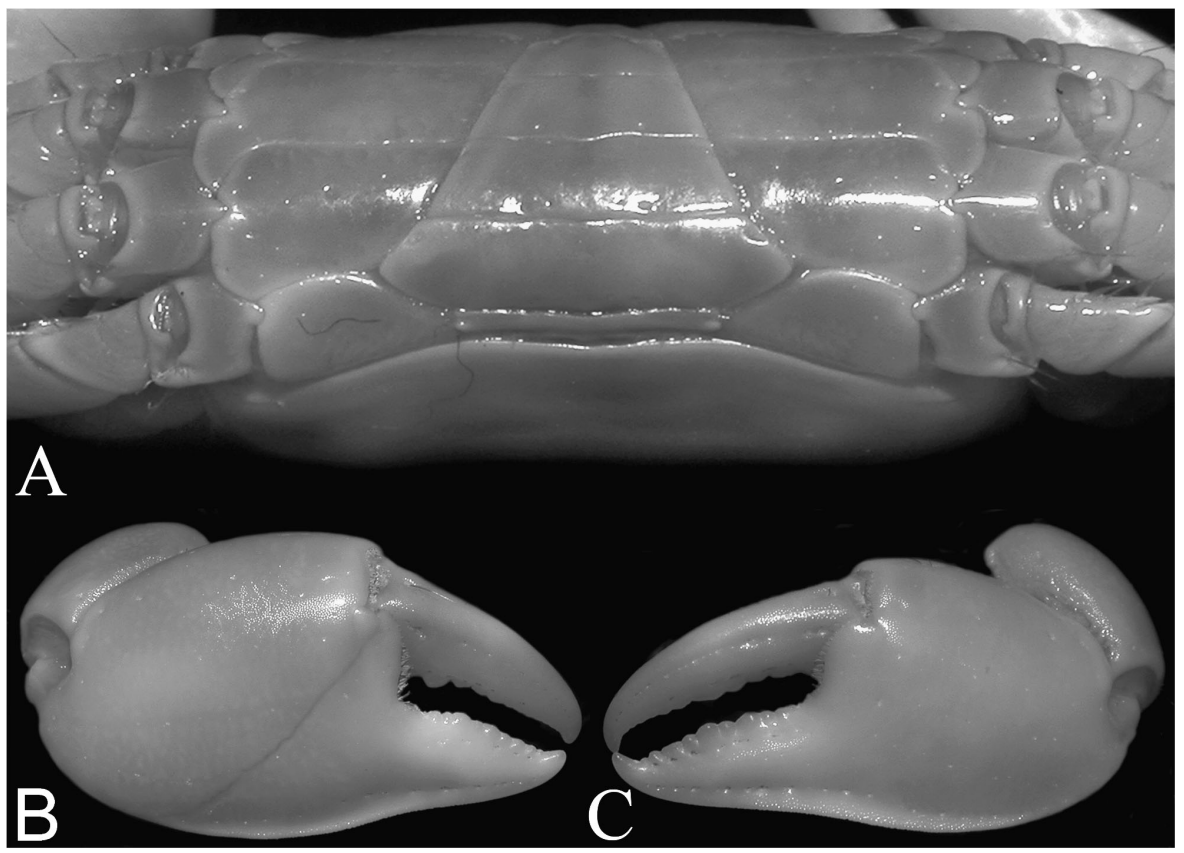

Fig. 2. Notonyx guinotae $\mathrm{n}$. sp., holotype, male $(15.5 \times 11.5 \mathrm{~mm})(\mathrm{MZB}$ Cru 2583). A, posterior part of thoracic sternum and abdomen; $\mathrm{B}$, outer surface of right cheliped; $\mathrm{C}$, outer surface of left cheliped.

somite 1 underneath carapace, somite 2 narrow, short, somite 3 widest, somites 4 to 6 tapering to triangular telson; telson longer than somite 6 (figs. 1C, 3D). G1 relatively long (fig. 4), curved, distal part produced, elongate, tip truncate; ventral subdistal part swollen. G2 long (fig. 5), tip slightly twisted, spoonshaped.

Females. - Chelipeds equal. Abdomen not rounded, ovate, not covering entire surface of thoracic sternum.

Colour. - Small specimens less than $11.4 \times 8.2 \mathrm{~mm}$ are a uniform ivory white. Large specimens, like the holotype $(15.5 \times 11.5 \mathrm{~mm}$, MZB Cru 2583), have a dark brown carapace with faint pinkish-orange markings, the chelipeds are pink with white fixed finger and the ambulatory legs are pinkish-white.

Remarks. - The morphologies of the G1 and G2 of $N$. guinotae n. sp. vary according to the size of the specimens. The smaller paratype male $(7.0 \times$ $5.8 \mathrm{~mm}$, MZB Cru 2586) has an almost straight G1 with no significant ventral swelling subdistally (fig. 4A) and the tip of the G2 is simple and not twisted (fig. 5A). In a larger paratype specimen $(7.8 \times 6.0 \mathrm{~mm}$, MZB Cru 2585), the ventral subdistal part of the G1 is moderately swollen and the tip slightly 


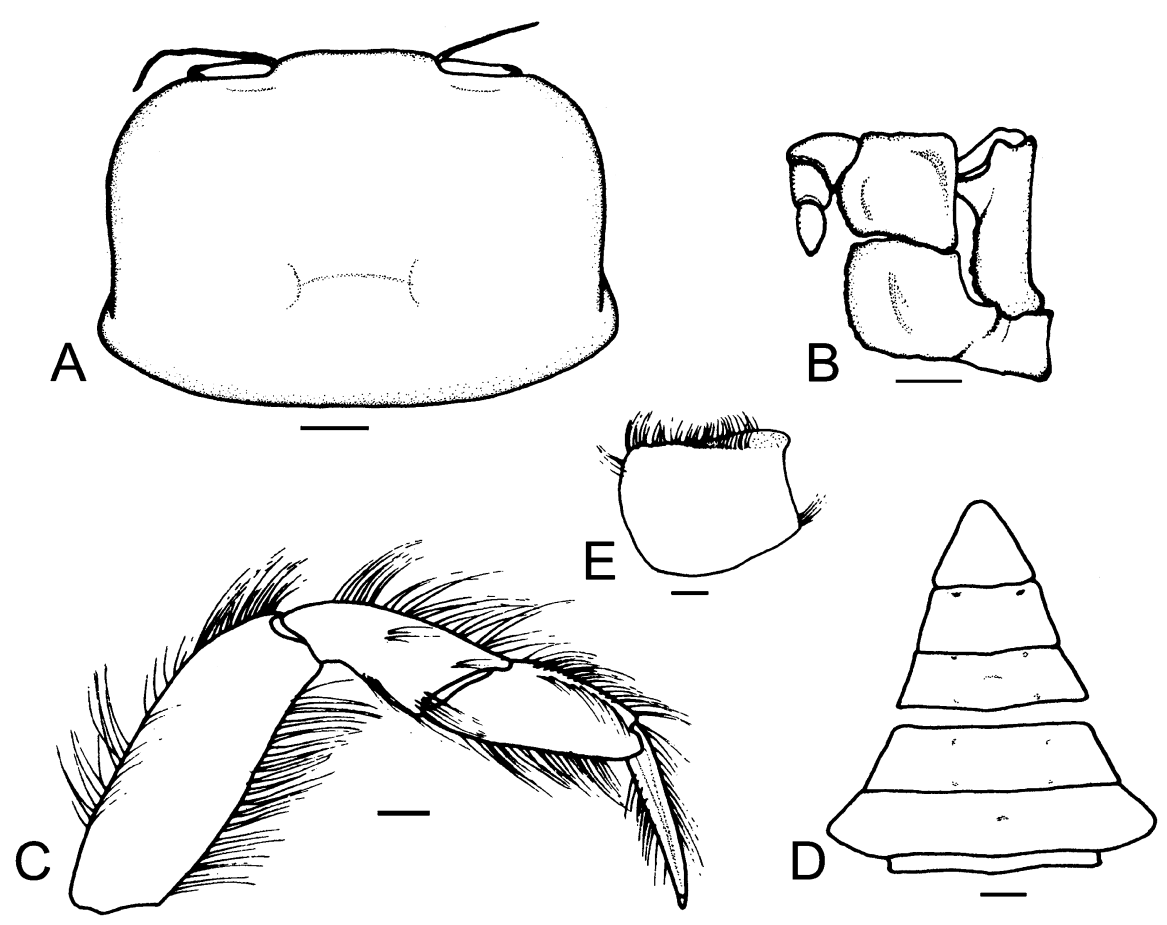

Fig. 3. Notonyx guinotae n. sp., holotype, male $(15.5 \times 11.5 \mathrm{~mm})($ MZB Cru 2583). A, carapace; $\mathrm{B}$, third maxilliped; $\mathrm{C}$, right fifth pereopod; D, abdomen; E, carpus of right cheliped. Scale: A \& $\mathrm{E}=2 \mathrm{~mm} ; \mathrm{B}-\mathrm{D}=1 \mathrm{~mm}$.

protruded (fig. 4C), with the tip appearing somehow bifurcate when viewed sublaterally (fig. 4D). The tip of the G2 is also slightly twisted (fig. 5C, D). In the $11.4 \times 8.2 \mathrm{~mm}$ paratype specimen (ZRC 2009.0745), the G1 is relatively longer, more curved, and the ventral subdistal part is prominently swollen with the tip clearly protruded (fig. 4E, F), and the tip of the G2 is twisted and directed upwards (fig. 5E, F). In the largest male (holotype, $15.5 \times$ $11.5 \mathrm{~mm}$, MZB Cru 2583), the G1 is relatively stouter, distinctly curved, with the ventral subdistal part significantly swollen, armed with more spines, and the tip protrudes very prominently (fig. 4G, H). The tip of G2 is now slightly curved and distinctly spoon-shaped (fig. 5G-I). Despite the changes in form, the small spines on the ventral surface of the subdistal part are always in the same position, albeit there are fewer of them in small specimens. The setae on the ambulatory legs also vary. The setae are short and scarce in smaller individuals, becoming gradually longer and denser in larger specimens.

The discovery of a third species of Notonyx in the Lesser Sunda Islands in Indonesia is noteworthy. Previously known from Indonesia are N. latus 



Fig. 4. Notonyx guinotae $\mathrm{n}$. sp. Male first gonopod. A, B, paratype male $(7.0 \times 5.8 \mathrm{~mm})(\mathrm{MZB}$ Cru 2586); C, D, paratype male $(7.8 \times 6.0 \mathrm{~mm})($ MZB Cru 2585); E, F, paratype male $(11.4 \times$ $8.2 \mathrm{~mm}$ ) (ZRC 2009 0745); G, H, holotype male $(15.5 \times 11.5 \mathrm{~mm})$ (MZB Cru 2583). Scales: $\mathrm{A}-\mathrm{D}=0.5 \mathrm{~mm} ; \mathrm{E}-\mathrm{H}=1.0 \mathrm{~mm}$.

(Kei Islands) and N. kumi (Sumbawa) with the latter also occurring in Japan (type locality). Notonyx guinotae is superficially most similar to N. kumi but can immediately be distinguished by its adult colour. Notonyx kumi has a 

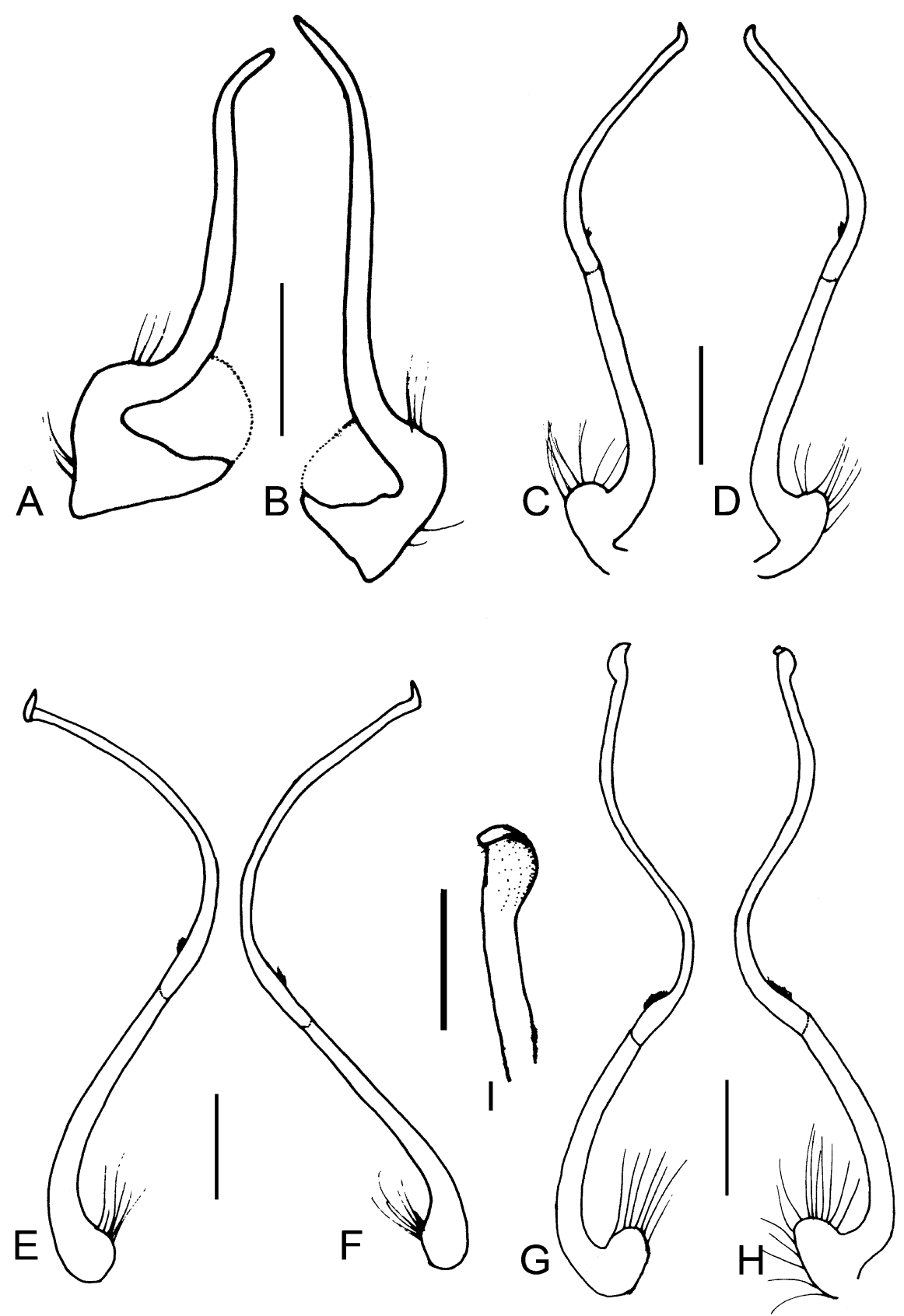

Fig. 5. Notonyx guinotae n. sp. Male second gonopod. A, B, paratype male $(7.0 \times 5.8 \mathrm{~mm})$ (MZB Cru 2586); C, D, paratype male $(7.8 \times 6.0 \mathrm{~mm})($ MZB Cru 2585); E, F, male $(11.4 \times$ $8.2 \mathrm{~mm}$ ) (ZRC 2009 0745); G-I, holotype male $(15.5 \times 11.5 \mathrm{~mm})$ (MZB Cru 2583). Scales: A-F, $\mathrm{I}=0.5 \mathrm{~mm} ; \mathrm{G}, \mathrm{H}=1.0 \mathrm{~mm}$. 
characteristic pattern of maroon lines and blotches on its carapace (Naruse \& Maenosono, 2009, fig. 3) while $N$. guinotae is uniformly porcelain-white in small individuals with the carapace becoming dark brown with pinkish white ambulatory legs in larger specimens. The G1s of the two species superficially resemble each other, but that of $N$. guinotae is distinctly more slender and elongated, with the distal part relatively less dilated (fig. 4G, H) whilst in $N$. kumi it is proportionately stouter and shorter, with the distal part more dilated (cf. Naruse \& Maenosono, 2009, fig. 2b, c). The G2 of $N$. guinotae is also gently curved, with the basal part only weakly expanded (fig. 5G, H) (sinuous with the basal part distinctly dilated in N. kumi, cf. Naruse \& Maenosono, 2009, fig. 2d). The male abdomen is relatively more slender (fig. 3D) (relatively broader in N. kumi, cf. Naruse \& Maenosono, 2009, fig. 2a), and the ambulatory propodi and dactyli are proportionately longer (fig. 3C) (relatively shorter in N. kumi, cf. Naruse \& Maenosono, 2009, figs. 1e, 3a). As these differences are based on comparisons of males of similar sizes, they are not likely to be caused by size issues. The good series of male and female specimens of $N$. guinotae also show the third maxilliped features, ambulatory leg proportions, and male abdominal shapes do not vary substantially in the taxon, and are therefore useful taxonomic characters at the species level.

Notonyx guinotae differs from $N$. latus in its relatively less broad carapace, proportionately shorter ischium and merus of the third maxilliped (fig. 3B) (cf. $\mathrm{Ng} \&$ Clark, 2008, fig. 2B, for $N$. latus) and proportionately shorter ambulatory legs (figs. 1A, 3C; see Ng \& Clark, 2008, figs. 1A, B, 2D, for N. latus). More importantly, their G1s and G2s differ very markedly. The ventral subdistal part of the G1 of $N$. guinotae is simple and partially dilated (fig. 4G, H) whilst that of $N$. latus has the distal part prominently hooked and the ventral subdistal part is not dilated ( $\mathrm{Ng} \&$ Clark, 2008, fig. 3). The G2 of $N$. guinotae is also curved with the basal part small (fig. $5 \mathrm{G}, \mathrm{H}$ ) whilst that of $N$. latus is sinuous with the basal part relatively larger (Ng \& Clark, 2008, fig. 3).

Ecology. - Notonyx guinotae was obtained from intertidal habitats with fine sand and gravel substrates. The area where it was collected has extensive seagrass beds. The crabs were burying in the sand and gravel, and were collected by sieving. The relatively simple and smooth carapace of Notonyx species is therefore very well adapted to living in this habitat.

\section{ACKNOWLEDGEMENTS}

We thank the personnel of Marine Bio-industry Implementation Unit, Research Center for Oceanography — Indonesian Institute of Sciences (LIPI) 
for their assistance in the field during the collection of the material for this study. The first author's research visit in Singapore was supported by a Raffles Museum Fellowship.

\section{REFERENCES}

Alcock, A., 1900. Materials for a carcinological fauna of India. No. 6. The Brachyura Catometopa, or Grapsoidea. Part II. Journal of the Asiatic Society of Bengal, 9 (3): 279456.

CAStro, P., 2007. A reappraisal of the family Goneplacidae MacLeay, 1838 (Crustacea, Decapoda, Brachyura) and revision of the subfamily Goneplacinae, with the description of ten new genera and eighteen new species. Zoosystema, 29 (4): 609-774.

Clark, P. \& P. K. L. NG, 2006. A new species of Notonyx A. Milne-Edwards, 1873 (Crustacea: Decapoda: Brachyuran: Goneplacidae) from the intertidal zone of Phuket, Thailand. Zoosystema, 28 (2): 539-551.

MACLEAY, W. S., 1838. On the brachyurous decapod Crustacea. Brought from the Cape by Dr. Smith. In: A. SMITH (ed.), Illustrations of the zoology of South Africa; consisting chiefly of figures and descriptions of the objects of natural history collected during an expedition into the interior of South Africa, in the years 1834, 1835, and 1836; fitted out by 'The Cape of Good Hope Association for Exploring Central Africa': together with a summary of African zoology, and an inquiry into the geographical ranges of species in that quarter of the globe, published under the Authority of the Lords Commissioners of Her Majesty's Treasury, Invertebratae. IV [1849]: 53-71, pls. 2, 3. (Smith, Elder \& Co., London).

Milne-EdWARDS, A., 1873. Recherches sur la faune carcinologique de la NouvelleCalédonie, Deuxième partie. Nouvelles Archives du Muséum d'Histoire naturelle, Paris, 9: $155-332$, pls. 4-18.

NARUSe, T. \& T. Maenosono, 2009. Notonyx kumi, a new species of goneplacid crab (Decapoda; Brachyura) from the Ryukyu Islands, Japan, and Lesser Sunda Islands, Indonesia. Bulletin of the National Museum Natural Sciences, Tokyo, (Supplement) 3: 183-189.

NG, P. K. L. \& P. F. Clark, 2008. A new species of Notonyx A. Milne-Edwards, 1873 (Crustacea: Decapoda: Brachyuran: Goneplacidae) from Indonesia. Zootaxa, 1987: 2026.

NG, P. K. L., D. Guinot \& P. J. F. Davie, 2008. Systema Brachyurorum, Part I. An annotated checklist of extant brachyuran crabs of the world. Raffles Bulletin of Zoology, (Supplement) 17: 1-286.

Stephensen, K., 1946. The Brachyura of the Iranian Gulf with an Appendix: The male pleopoda of the Brachyura. Danish Scientific Investigation in Iran, 4: 57-237.

TESCH, J., 1918. The Decapoda Brachyura of the Siboga-Expedition. II. Goneplacidae and Pinnotheridae. In: Uitkomstem op Zoologisch, Botanisch, Oceanographisch en Geologisch gebied verzameld in Nederlandsch Oost-Indië 1899-1900 aan boord H.M. "Siboga" onder commando van Luitenant ter Zee 1e kl. G.F. Tydeman uitgeven door Dr. Max Weber. Siboga-Expeditie Monographie, 39c1 (84): 149-295, pls. 7-18. (Brill, Leiden).

First received 28 June 2009.

Final version accepted 14 July 2009. 